\title{
AN AMERICAN LOOKS AT LEGAL EDUCATION IN NEW ZEALAND
}

\author{
Allison Dunham
}

In a previous article, I compared the Arts units requirements for law students in the United States with those in New Zealand and your Editor has suggested that I might continue the comparison in the present article. In this article, I shall make any comparisons or contrasts informally; and the order in which they appear is not necessarily that of importance or of difference or similarity.

If I am going to look at legal education in New Zealand, it is proper, I think, that I disclose my point of reference which is, of course, legal education in the United States. Because of our great diversity this is difficult, but the pattern is fairly constant. Admission to practice is governed by State statute or by Rules of Court of the State in which the applicant resides. As I indicated in an earlier article, these rules in general require a specified number of units or time spent on arts subjects. In addition, they require that an approved law school certify that the applicant has successfully completed the required amount of time and professional units in the law school; and, finally, the rules in all States provide that the applicant must successfully pass an examination prepared by a specified official agency (usually a committee of the State Law Society or nominees from the Society made by the State Supreme Court).

After the educational requirements have been satisfied there is a procedure for checking the applicant's character, and, finally, a motion is made to the Court for admittance to practice.

We do not distinguish between barristers and solicitors as you do; the requirements are the same; the terms are used synonymously by profession and public; and the applicant is admitted to practice.

Since I commented in the earlier article on the Arts units I will keep to the professional subjects in this article.

Professor of Law, the Law School, University of Chicago. Visiting Lecturer in Law, Victoria University College on a Fullbright Grant, 1953. The paper was first published at [1954] NZLJ 56. 


\section{PROFESSIONAL TRAINING IN LAW IN THE UNIVERSITY}

In the United States, the Universities determine what a student studies for the LLB which is solely a University degree; the statutory rules determine only the time which must be spent in University study.

The basic unit of time in the United States is a semester of 15 weeks. Most of our units are three class-hours per week for one semester. Some, particularly those in the first year, last for a whole year; but most other courses are of 15 weeks' duration. So that in a "threehour" course our students would have 45 class-hours of instruction during the academic year.

All the better universities require more for the LL.B. degree than the State statutes require. Thus, in New York, the statute require 72 semester hours while Columbia require 78. In Illinois, the requirement is about 70. My University requires about 80 semester hours. This is for full-time students, who are expected to complete this requirement in three academic years of about 30 weeks during which time the student will have from 12 to 15 (maximum of 17) class hours per week.

For part-time students, the statutes usually require four academic years for the professional subjects by limiting the number of classes a student may attend in one week to ten, although the usual number is closer to seven.

What do our students study in their professional subjects?

The subjects include all of those which you have in your list of professional subjects for an LL.B. degree, if the student wishes. Probably, our student studies the subjects which he does take in more concentrated form. There is no necessary relation between the subjects which a student studies in his University (and on which he is examined by the University) and the subjects on which the student will be examined when he applies for admission to practice. If a student omits to study in the University subjects on which he will be examined in the State examination, he will prepare himself in those subjects by independent reading. This is a very common practice; and the students are encouraged to study material which interests them, and to prepare for the State examination by reading. Thus, the most popular courses for our students today are administrative law, federal taxation, and trade regulation; yet in almost no State will the student be examined on these subjects.

In general, the first academic year for a law student is prescribed. The student will have three class-hours per week for 30 weeks in each of three subjects: property (real and personal), torts, and contracts. He will have a 15 week course for three hours per week in criminal law and in procedure. He will complete his programme with some course prescribed by his University from the following list:" legal history, legal reasoning, equity, agency, public law. In the second and third years, the students have a great deal of choice; 
but their choices tend to fall into a fairly common pattern. Almost all take constitutional law, corporation law, accounting for lawyers, procedure and trusts. The other courses taken in the second year include family law, wills and estate administration, future interests, administrative law, trade regulation, creditors' rights, and sales and bills of exchange transactions. In the third year, the students generally elect to take conflict of laws, evidence, jurisprudence, federal taxation, and labour law. The programme is filled out from among the subjects available for second-year students: international law, comparative law, Roman law, or specialized subjects such as admiralty, patent law, and copyright law.

How does this compare with your situation? With the possible exception of Roman Law, our students will study something in all of the areas of law listed in your syllabus for the LL.B. degree. But they will study much more than that and in some areas such as property and procedure a great deal more thoroughly than your present syllabus.

As I have indicated, our students have two sets of examinations to take, one of which you would label "external." Our law students must take each year an examination given by the University in the units which he is taking. Then, about six weeks after he completes his University training and receives his LL.B. degree, he will take a comprehensive professional examination administered by some official state agency (as described above) which will cover many areas of law some of which the student has not studied and some of which he studied three years before. This comprehensive examination is a two-day or three-day examination and includes all of the subjects on your list of professional subjects for the LL.B. degree, except International Law and Roman Law.

I think the original reason for our double examination system was the fact that we at one time had "proprietary law schools," an offshoot of the articled-clerk system, which were not very good, and, to insure uniformity of minimum standards the compulsory State examination was instituted. If you look at the statistics, the double set of examinations is a waste of time for the students from our good State and private Universities (such as Harvard, Chicago, Columbia, etc.). Where the average passes for the official examination is say 66 per cent, better than 85 per cent, of the students from our good Universities pass the first time they take the official examination.

The advantage of the double examination system, as I see it, is two-fold: First, it is a "practical" compromise answer to the vexatious question: who is to determine the requirements of legal education - the Universities where law is taught or the law societies? This system answers that both the law societies and the Universities determine the content of legal education. Secondly, the system permits the Universities to "experiment" with and add to the requirements for a good lawyer, and the Law Societies to add to the official requirement after the Universities have proved their position to be sound. For example, our Universities have taught federal taxation and administrative law for many years; the State 
law societies are now adding these subjects to the list of subjects on which there will be official examinations.

What kinds of examinations do we have? One part of our examination both University and official is, of course, to test whether the student has acquired a minimum amount of knowledge of principles or rules of law. For this objective "short-answer" (eg true and false, fill in the blanks, and "list 4 ways" types of questions) are often used. But the major objectives of our examinations, both official and University, is to test ability and skill in analyzing problems and applying principles remembered. This is on the theory that it is rare that a lawyer will be asked to give an "off the cuff" answer to a client so that he should not be expected to "remember" that Foakes $v$ Beer decided such and such a rule, or that Section 15 of a statute prescribed such and such in detail.

It is said of the late Chief Justice Stone of the United States Supreme Court that, when he was a professor of law teaching trusts he gave the top grade in the class to a student on whose paper he had written: "Very ingenious use of a principle but I do not think the Courts will agree with you." Thus the Chief Justice regarded skill, imagination and analysis rather than knowledge as of most importance.

Our students are expected to know or comprehend principles or rules of law, but they are not expected to remember the name of the case from which it comes. Thus, a student on examination should know the rule of Foakes $v$ Beer, but he need not remember that it came from Foakes $v$ Beer. This is, perhaps, due to the fact that our Courts appear to have adhered more closely than have your courts to the common-law theory of case law as developed in England. Cases establish principles and rules for us as they did for Bramwell, Blackburn and Scrutton. The principle is the precedent and the case is followed because of the principle established, not because it was decided. An examination joke in our law schools illustrating this point is the answer the professor got when he asked on examination: "What is the rule in Shelly's case?" The student's answer read: "It is the same rule as that in any other case; the common law is, no respecter of persons, its principles apply to all equally."

Some of our University examinations are what we call "open-book" examinations - ie, the students are permitted to take notes and books with them. None of our official examinations is of this type, probably because of technical difficulties. For one thing, the examiner must, if he is fair, limit the materials to be taken, to those of which there are sufficient copies for each student to take into the examination if he wishes. Unless there are, for example, twenty copies of the report of Foakes $v$ Beer available, no student in a class of twenty should be permitted to take a copy of the report of Foakes $v$ Beer into the examination. 


\section{METHODS OF INSTRUCTION}

As those of you who have heard me know, the uniform method of instruction is some variant of the case-method. The essence of the case-method is that the students study a legal problem, and, by the socratic method (class discussion) the applicable principles are worked out in class. The students work it out for themselves with the aid of the professor, and do not take it on faith that Garrow has correctly done the work for them. The value of the method is that students learn by using the reasoning of Courts and that it makes the class more exciting and stimulating than the usual lecture method.

This method of instruction also openly asserts a factor in education which the lecture method frequently conceals. Not every subject listed in the syllabus is mentioned in class. The students are told that in certain areas he must master the material himself. Thus the professor of contracts may tell his students to master "capacity of parties" or "accord and satisfaction" by themselves; but that they will spend five weeks of class time on the intricacies of consideration. There is no feeling of a need to note every point on the syllabus in class.

I might add that many of you have told me that the case-method was too slow to cover all the material which "needed" to be covered in class. When I have questioned you (particularly if you were a part-time lecturer) I have found that, in the lecture method, you may "skim" through large sections of the syllabus and expect the student to acquire his knowledge by independent reading. This is also true of the case-method; the difference is that the professor does not pay "lip-service" to the syllabus; he teaches in class only that which he thinks important and openly tells the students to learn by reading all other material.

\section{LAW OFFICE PRACTICE FOR STUDENTS}

The most significant difference in legal education is the contrast in attitude toward lawoffice practice as part of legal education. In most States, if not all, in the United States, practical experience in an office is not a pre-requisite to admission to practice by the State. Not only is practical experience not a pre-requisite, it is not the custom as it is here. Even students in our part-time law schools do not as a rule work in law offices; if the reason they work while studying is money, they can earn more money elsewhere. It is not the custom of students, and it is not the custom of lawyers. Our law firms are not interested in having unqualified clerks cluttering up their offices.

This is a basic difference in attitude as to the significance of practical training. I have met lawyers and students here who regard the office experience as everything and the University training as something for which there is no reason other than the fact that it is in the statute books or that it is traditional. There are lawyers and students in the United States who think our University training should be more "practical," but even in this 
criticism there is an assumption that practical training can be obtained from formal University instruction.

Our beginners do need practical training. A graduate of our university law schools is best qualified to prepare opinions and write letters of advice. He is least qualified to draft pleadings and instruments and to handle witnesses in court. The drafting problem is treated as one of training the beginner in the location of the form book on the office shelves. I think our law firms tend to look on the practical training as analogous to training in "ground rules" in golf - ie, the training is in matters of localized importance for the firm or the particular Court before which it practices. Accordingly, it is not thought that the practical training should have priority over formal training in principles, and in no event should such practical instruction interfere with or detract from the training given by the University in fundamental principles.

There is, of course, one thing that law office training can do. It can do what nothing else can do - train in those traditions of the profession for which there is no reason other than "it is done this way" or "it just isn't done." How well the elder lawyer trains the younger in this respect depends on the skill and sense of responsibility of the elder lawyer. If he does not take his responsibility seriously and is most interested in having a "clerk" to do menial tasks, he will not work at the training function of clerking.

I should add that this difference in attitude about the importance of practical training for a beginner appears to me not to be confined to the legal profession but to permeate the economy of both countries. I get the feeling here that in most jobs a young man has the status of a beginner for a much longer time than in the United States. In the United States beginner means absence of any practical training, and that after some training it is possible to move to another job no longer in the position of beginner, even though the move takes place before the end of what is usually thought of as the training period. Beginner is not a status in the United States as much as it is lack of any training.

Secondly, in work generally there seems to me to be less willingness to substitute formal education for practical training here than we have in the United States. We not only expect education to do more for the employee than you do, but we tend to regard the practical training as being on the same level of importance as that of discovering the period set aside for, and the place for, morning and afternoon tea - practicalities of a job are quickly taught and quickly learned on the job.

\section{STUDENTS}

Our students are much older than yours because of the length of our liberal Arts requirements before professional study is undertaken. I think your students, at least if they do the double sixth form, have better high school and probably better liberal Arts training than many, if not most, of our students. Our students become progressively more selected 
than are yours, so that our failure rates, I think, may be less than yours. Both our colleges and our law schools require our students to maintain a certain minimum quality of work or they are removed from the University. This means that at least by the end of the first year of professional work there are very few students remaining who do not have the intellectual qualifications for becoming a lawyer. It is accordingly not unoommon for a student to fail property, a first-year course; but it is exceedingly rare that any student remaining in school will fail the third-year property course.

Of course, no one can say which "system" of legal education is the best. There are good points in both and bad points in both, and, whatever system of education a country has, it should be arranged so as to accentuate the "good" points in that country's legal profession. I think the important thing in any country, however, is that members of the Law Society and the law teachers are continually asking themselves whether legal education can be improved and the why of the present methods.

It appears to me that your profession is about to enter upon a period of debate concerning legal education. While this may be aggravating to some of you, and the nerves of others may become frayed, I think nothing is lost by such agitation and re-examination of the existing system, even though the final conclusion may be to leave it as it is. The important thing is the approach to the question. No one can go wrong if he asks "What is the best legal education?" I agree with Dean Griswold, however, that it is impossible to shape legal education in terms of the needs of the profession for cheap clerks.

The very process of formulating valid contemporary reasons for things now being done produces change, and doers attempt to make the practice conform to the reasons given for the practice. At least, so the common law teaches. 
(1999) 30 VUWLR 